\title{
Students' Experiences in Sport-Based Physical Education: [More Than] Apologies are Necessary
}

\section{Catherine D. Ennis}

Those of us who have been participants in sport for much of our lives often find it a time-consuming and irrelevant task to defend the joys and rewards of physical activity to the uninformed or the uninitiated. Some physical education teachers are amazed at the energy they must spend motivating students to dress and participate in physical activity at the lowest intensity levels (Ennis, 1995). Even physiologists are modifying the "criteria" for health-enhancing exercise to make it more palatable for the majority of Americans who enjoy a sedentary lifestyle and are unconcerned with target heart rate zones. While many Americans watch sport, far fewer participate in sport as a physical activity. Corlett, in his efforts to focus on the benefits of sport, glazes over the problems insidious in some sporting contexts. I will focus on problems plaguing sport-based, public school physical education that lead to discriminatory and abusive practices. I am most concerned with the policies used to perpetuate discriminatory sporting practices in schools, and believe disenfranchised individuals deserve an apology.

Although sport has many potential virtues, this message would be stronger if Corlett defined the boundaries of sport pedagogy he is addressing and focused on how all individuals can benefit from these opportunities. He begins by addressing his arguments to school sport, but then changes to focus on high-level performance as an exemplary ideal for individuals in school programs. He never considers the diverse characteristics of the individuals involved in school sport or the wide variety of contexts in which sport-based school curricula are implemented (e.g., Ennis, 1996). This oversight contributes to an elitist perspective on sport pedagogy that constrains, rather than facilitates, our ability to acknowledge and address negative sport practices in schools.

The role of sport in physical education is important because physical education influences individuals' perspectives on physical activity and their ability to participate in and appreciate sport. Although there are many sport-based physical

Catherine D. Ennis is with the Department of Kinesiology at the University of Maryland, College Park, MD 20742-2611. 
education programs that are enjoyable and educationally valuable to the majority of participants, there is increasing evidence that sport, as experienced in some physical education classes, is neither positive nor beneficial. It is far removed from the activities that Corlett proposes as essential to the preservation of creativity and virtue, and the exploration of human limits.

\section{Students' Experiences With Sport}

Students in sport-based physical education confirm that some experiences have a negative impact on their perspectives on physical activity and do not contribute to positive personal or educational experiences. For example, Portman's (1995, pp. 450-451) interviews with 13 low-skilled 6th graders suggested they were unhappy in sport-based physical education. Students remarked: "I don't like PE when we play volleyball." (Paul); "I try my best, but I am just terrible at games." (Heather); "I know how to throw it (football), but I just don't like it. I just don't want to learn it." (Marsha); and "I let the ball go past me, and it hit me in the face. I am afraid of balls. I just want to sit out." (Yasmine).

Research in physical education classes has provided examples of students who dress for sport classes, but do not enter the game by their own choice, and those who, if they do agree to stand on the field or court, refuse to become involved in the competition much to the chagrin of teammates and sport pedagogists (e.g., Carlson, 1995; Cothran \& Ennis, 1996). Both boys and girls reported an intense dislike for the embarrassment and discomfort they had experienced in sport-based physical education. Students also admitted they were often the subject of verbal and, at times, physical abuse from peers (Portman, 1995).

We owe these students an apology. No one should be required to endure these insults in an educational situation. Further, we can and must change the negative practices incorporated in physical education curricula that influence how students experience sport in schools. While it is notable to discuss the potential for creativity, exploration of human limits, and teaching of human values, we must ask which students are receiving these opportunities and benefits, and why so many sport pedagogists continue to ignore these practices.

\section{Sport as Dominance}

Until recently, sport was the primary activity in which students engaged in physical education. Historically, boys, in particular, participated in intensely competitive sports as the principal activity in physical education. Feminists, such as Smeal, Carpenter, and Tait (1994); Vertensky (1992), pointed out that sport was developed primarily by men for men and boys. It has been used as an acceptable way to demonstrate aggression toward others and continues to be used by men to demonstrate their prowess and dominance in socially acceptable ways. Likewise, in many sport-based physical education programs, stronger, faster, and more aggressive players are encouraged to "eliminate" weaker, slower, and more timid individuals. When a few aggressive individuals dominate activity in physical education, the majority of the class, both boys and girls, are discriminated against and denied access to positive forms of sport as physical activity. We owe students an apology when this is permitted in an educational environment, and we must take steps to eliminate this practice. 
Female participation in men's sport continues to come at great cost both in limited access to meaningful sporting opportunities and in the negative social and sexual slurs that result when they participate successfully (e.g., Griffin, 1992; Postow, 1988). Girls reported the play in physical education was too rough, and that other students' and parents' negative comments regarding masculinity or sexual orientation were not worth the price for participating. Some students explained they were afraid physically to participate with stronger, faster boys in games that these boys "own" (Cothran \& Ennis, 1996). Although this commentary is not new to physical education (e.g., Metheny, 1972), there have been few changes in the way many middle and high school sport-based programs address the roles of low-skilled individuals, in general, and girls and women, in particular.

In sport-based physical education, minority individuals are not defined as much by ethnicity, race, or gender as by lack of skill. Skillfulness is the currency that buys opportunities to practice in class, and prestige and status on the court and in the locker room. Physical education programs that do not provide all students with interesting, meaningful, and intrinsically rewarding opportunities to participate skillfully in games and sport are discriminatory and limit access not only to the joys of participation, but also to many personally and socially rewarding and satisfying ways to gain the health-related benefits of physical activity.

\section{Sport as a Positive Educational Experience}

There are a few models, however, that have been proposed to provide more positive experiences in sport for diverse students. Siedentop (1995) and Grant (1994) presented a concrete and pragmatic approach, described as "Sport Education," to promote the benefits of sport for all participants. Teachers who have used this model report that low-skilled players, some of whom are girls, choose to be more actively involved because they are protected and supported, both by their teacher and their teammates. They become more skillful and assume sporting roles that are meaningful for them and respected by significant others, such as higher skilled classmates. Other advocates of sporting opportunities for all individuals propose new sports that do not favor strength and power (e.g., English, 1988; Young, 1988). Instead, they offer all individuals the opportunity to participate in sport and games in which they will be successful and feel physical and emotional safety.

To promote positive sport, pedagogists must provide a meaningful, instructionally effective, and safe environment for all participants. It is unrealistic to assume these goals can be reached as long as aggressive individuals are permitted to dictate sport practices in physical education. Apologies are necessary to individuals who would like to participate, but who have never felt safe. Likewise, we should apologize to those who have tried to participate, but have been embarrassed or never felt comfortable exploring their physical limits.

The advent of opportunities for students to select courses or activities in an elective physical education program is leading to the decline in sport participation. Although in the past these students were part of a captive audience, elective programs now are giving them opportunities to avoid demoralizing sport experiences. Sport-based physical education in many programs is being superseded rapidly by physical activities that provide opportunities for all students to learn kinesiological knowledge, understand themselves physically and emotionally, and work cooperatively in interesting and meaningful physical activities. Without major ef- 
forts to reform sporting practices in schools, sport will continue to be attacked as discriminatory and allocated less time and resources in school-based sport pedagogy. Efforts to reform these programs are essential to the well-being of all school children. In the final analysis, apologies are hollow and meaningless without concerted efforts to include all students in positive, school-based sporting experiences.

\section{References}

Carlson, T.B. (1995). We hate gym: Alienation from physical education. Journal of Teaching in Physical Education, 14, 467-477.

Cothran, D.J., \& Ennis, C.D. (1996, April). Nobody said nothing about learning stuff. Paper presented at the annual meeting of the American Educational Research Association, New York.

English, J. (1988). Sex equality in sports. In W.J. Morgan \& K.V. Meir (Eds.), Philosophic inquiry in sport (pp. 329-334). Champaign, IL: Human Kinetics.

Ennis, C.D. (1995). Teachers' responses to noncompliant students: The realities and consequences of a negotiated curriculum. Teaching and Teacher Education, 11, 445-460.

Ennis, C.D. (1996). When avoiding confrontation leads to avoiding content: Disruptive students' impact on curriculum. Journal of Curriculum and Supervision, 11, 145-162.

Grant, B. (1992). Integrating sport into the physical education curriculum in New Zealand secondary schools. Quest, 44, 304-316.

Griffin, P. (1992). Changing the game: Homophobia, sexism, and lesbians in sport. Quest, 44, 251-295.

Metheny, E. (1972). The symbolic power of sport. In E. Gerber (Ed.), Sport and the body: A philosophical symposium (pp. 221-227). Philadelphia: Lea and Febiger.

Portman, P.A. (1995). Who is having fun in physical education classes? Experiences of sixth-grade students in elementary and middle schools. Journal of Teaching in Physical Education, 14, 445-444.

Postow, B.C. (1988). Women and masculine sports. In W.J. Morgan \& K.V. Meir (Eds.), Philosophic inquiry in sport (pp. 359-365). Champaign, IL: Human Kinetics.

Siedentop, D. (1995). Sport education: Quality physical education through positive sport experiences. Champaign, IL: Human Kinetics.

Smeal, G., Carpenter, B., \& Tait, G. (1994). Ideals and realities: Articulating feminist perspectives in physical education. Quest, 46, 410-424.

Vertinsky, P.A. (1992). Reclaiming space, revisioning the body: The quest for gender-sensitive physical education. Quest, 44, 373-396.

Young, I.M. (1988). The exclusion of women from sport: Conceptual and existential dimensions. In W.J. Morgan \& K.V. Meir (Eds.), Philosophic inquiry in sport (pp. 335-341). Champaign, IL: Human Kinetics. 